\title{
PENENTUAN TOTAL FENOLIK DAN AKTIVITAS ANTIOKSIDAN EKSTRAK ETANOLIK DAUNSAMAMA (Anthocephalus macrophylus) ASAL TERNATE, MALUKU UTARA
}

\section{DETERMINATION OF TOTAL PHENOLIC CONTENT AND TOTAL ANTIOXIDANT ACTIVITIY IN ETHANOL EXTRACT OF SAMAMA LEAF (Anthocephalus macrophylus) FROM TERNATE ISLAND, NORTH MALUKU}

\author{
Khadijah $^{1)}$, Ahmad Muchsin Jayali ${ }^{1)}$, Sudir Umar ${ }^{1)}$, Iin Sasmita ${ }^{2)}$ \\ ${ }^{1)}$ Staff Pengajar Prodi Pendidikan Kimia Universitas Khairun, Ternate \\ ${ }^{2)}$ Mahasiswa Prodi Pendidikan Kimia Universitas Khairun,Ternate \\ Corresponding Author :talimbangan@gmail.com
}

Submit : 02 November 2017 Accepted : 15 November 2017

\begin{abstract}
The total phenolic content and antioxidant activity of Samama (Anthocephallus macrophyllus) plants from Ternate Island, North Maluku was conducted, and find the relationship between total phenolic content and antioxidant activity. The ethanol extract was obtained by maceration the leaf of Samama which has been dried and separated according to leaf age (young and old). Determination of secondary metabolite extracts was performed by phytochemical screening indicating the presence of alkaloid, phenolic, steroid, and saponin compounds. The total phenolic extract was determined by the Folin-Ciocalteu method obtained by total phenolic content of $119.68 \mathrm{mgGAE} / \mathrm{g}$ for young leaves and $210.22 \mathrm{mgGAE} / \mathrm{g}$ for the older leaves. Antioxidant activity was analyzed by DPPH method obtained IC50 value $80.34 \mu \mathrm{g} / \mathrm{mL}$ on young leaves, and $43.49 \mu \mathrm{g} / \mathrm{mL}$ on old samama leaf. The total content of phenolic samama leaf extract and its IC50 value show linear relationship $y=-2,4647 x+317,22$ with determination value $\mathrm{R} 2=0.9996$.
\end{abstract}

\section{Keywords:Ethanol extract,, Anthosephalus macrophyllus, The Phenolic content, Antioxydants}

\section{PENDAHULUAN}

Penggunaan sumber daya alam sebagai obat tradisional lebih diminati karena relatif tidak menimbulkan efek samping, berbeda dengan obatobat sintetik yang seringkali mengakibatkan efek samping yang lebih berbahaya bagi kesehatan. Apalagi setelah krisis ekonomi yang dialami oleh beberapa negara asia termasuk Indonesia menyebabkan melonjaknya harga obat-obat sintetik, sehingga daya jangkau masyarakat terhadap obat-obat sintetik semakin rendah. Penggunaan bahan alam sebagai obat tradisional dan sebagai bahan dasar obat merupakan salah satu alternatif pengobatan [1,2]. Hasil survei etnobotani memperlihatkan bahwa salah satu tumbuhan yang potensial adalah tumbuhan tropika Indonesia yang dikenal dengan nama Jabon Merah. Tumbuhan tersebut banyak ditemukan di daerah Maluku, Maluku Utara dengan nama daerah Samama (Ternate, Halmahera) dan nama latinnya Anthosephalus macrophyllus.

Jabon merah memiliki daya tarik tersendiri untuk diteliti.Masyarakat Maluku Utara terutama
Ternate dan Halmahera memanfaatkan kulit batang sebagai obat tradisional yang memiliki khasiat penambah stamina, penyubur kandungan, dan dapat menurunkan kadar kolesterol darah. Dikonsumsi dengan cara meminum air rebusannya. Khusus untuk bagian daun digunakan sebagai obat kumur dengan cara diekstrak terlebih dahulu [3]. Namun penyelidikan dan informasi lebih mendalam tentang kandungan kimia yang terdapat pada jabon merah ini belum banyak ditemukan.

Pemanfaatan tumbuhan obat oleh masyarakat sering kali tidak mengetahui kandungan kimia dari tumbuhan tersebut, sehingga dalam menentukan jumlah dosis pemakaiannya masyarakat hanya mengandalkan pada pengalaman dan perkiraan semata. Kandungan senyawa kimia yang terdapat dalam obat tradisional selain berkhasiat dapat juga menyebabakan efek samping yang merugikan jika dikonsumsi sembarangan (tanpa kontrol). Uji kandungan kimia dilakukan melalui analisis fitokimia secara kualitatif. 
Zat alami yang diekstrak dari tumbuhan ini, dapat bertindak sebagai sumber potensial karena bersifat photoprotective. Hal ini dikaitkan dengan kenyataan bahwa tanaman tidak bisa terhindar dari paparan sinar matahari karena tanaman memerlukan matahari untuk proses fotosintesis. Meskipun begitu, tanaman memiliki mekanisme perlindungan diri sendiri sehingga tanaman tidak mengalami kerusakan [4]. Hal tersebut memberikan gambaran mengenai kemampuan tanaman untuk melindungi kulit melalui senyawa yang terkandung dalam tanaman berupa senyawa bioaktif seperti fenolik dan didukung oleh adanya senyawa yang bersifat antioksidan [5]

Penelitian ini difokuskan untuk mengetahui kandungan total fenolik dan aktivitas antioksidan yang dimiliki ekstrak etanolik yang terdapat pada Anthosephalus macrophyllusatau pohon samama alias Jabon merah, serta hubungan antara total fenolik dan aktivitas antioksidan yang dimiliki oleh daun samama yang berasal dari Kota Ternate, Maluku Utara

\section{METODE PENELITIAN}

\section{Alat dan Bahan}

Alat-alat yang digunakan dalam penelitian ini antara lain neraca digital, rotavapor, seperangkat alat gelas, dan spektrofotometer UVVIS merk Shimadzu UV-1800.

Bahan-bahan yang digunakan dalam penelitian ini antara lain daun Samama Anthocephalus macrophyllus, larutan etanol 95\%, metanol, DPPH, Akuades, kapas, aluminium foil, pereaksi LB, pereaksi meyer, pereaksi Dragendorf, larutan Folin-Ciocalteu, asam galat, $\mathrm{Na}_{2} \mathrm{CO}_{3}$, pita Magnesium dan Aquades

\section{Preparasi Sampel}

Sampel yang digunakan adalah daun samamayang dipisahkan berdasarkan umur daunnya yaitu sampel daun muda (daun ketiga dari pucuk) dan daun tua (daun yang dekat dengan batang cambium) yang diambil di sekitar Gambesi, Kota Ternate, Maluku Utara. Sampel lalu dibersihkan dan dikeringkan tanpa cahaya matahari langsung.

\section{Maserasi dan Ekstraksi}

Sampel kemudian diblender menjadi serbuk di laboratorium Kimia FKIP Universitas Khairun Ternate, dan dimaserasi dengan etanol 95\% selama 3 x 24 jam pada suhu kamar. Ekstrak etanol yang diperoleh dikumpulkan dan diuapkan dengan rnenggunakan rotavapor hingga diperoleh ekstrak etanolik kental lalu ditirnbang.

\section{Identifikasi}

Ekstrak etanol dari daun di skrining fitokimia untuk mengetahui kandungan metabolit sekunder berupa alkaloid, flavanoid, fenolik, steroid dan saponin, yang ada pada daun Samama [6].

\section{Uji Alkaloid}

Ekstrak sampel sebanyak 0,2 g ditambahkan $5 \mathrm{ml}$ ammonia 25\% lalu digerus dengan lumpang. Ditambahkan $20 \mathrm{ml}$ kloroform, digerus kembali dan disaring. Filtrat dimasukkan ke dalam tabung reaksi, ditambahkan $\mathrm{HCl} 10 \%$ lalu dikocok. Larutan bagian atas (fasa kloroform) diambil, lalu dibagi dua ke dalam tabung reaksi, masingmasing ditambahkan pereaksi Dragendorff, Mayer dan Wagner. Apabila terbentuk endapan merah bata dengan pereaksi Dragendorff, endapan putih dengan pereaksi Mayer dan endapan coklat dengan pereaksi Wagner menunjukkan adanya golongan senyawa alkaloid.

\section{Uji Flavonoid}

Ekstrak sampel sebanyak 0,2 g ditambahkan 0,05 $\mathrm{g}$ serbuk magnesium $(\mathrm{Mg})$ dan $0,2 \mathrm{ml}$ asam alkohol (campuran $\mathrm{HCl} \mathrm{37 \%} \mathrm{dan} \mathrm{etanol} \mathrm{96 \%}$ dengan volume yang sama), kemudian ditambahkan $2 \mathrm{ml}$ amil alkohol lalu dikocok dengan kuat dan dibiarkan hingga memisah. Terbentuknya warna merah, kuning atau jingga pada lapisan amil alkohol menunjukan adanya senyawa golongan flavonoid.

\section{Uji Fenolik}

Ekstrak sampel 0,2 g di tambahkan dengan larutan $\mathrm{FeCl}_{3} 1 \%$. Hasil ditunjukkan dengan terbentuknya warna hijau, merah, ungu, biru tua, biru, biru kehitaman, atau hijau kehitaman [6].

\section{Uji Steroid dan Triterpenoid}

Ekstrak sampel sebanyak 0,2 g dimasukkan ke dalam erlenmeyer bertutup kasah, ditambahkan 20 $\mathrm{ml}$ dietileter, dimaserasi selama 2 jam lalu disaring. Sebanyak $5 \mathrm{ml}$ filtrat diuapkan dalam cawan penguap hingga diperoleh residu, lalu ditambahkan pereaksi Liebermann-Burchard. Terbentuknya warna merah atau hijau menunjukan adanya senyawa golongan steroid atau triterpenoid.

\section{Uji Saponin}

Ekstrak sampel sebanyak 0,2 g ditambahkan 100 $\mathrm{ml}$ air panas, dididihkan selama 5 menit, lalu disaring dengan kertas saring (larutan A). $10 \mathrm{ml}$ larutan A dimasukkan ke dalam tabung reaksi dan 
dikocok dengan kuat secara vertikal selama 10 detik. Terbentuknya busa setinggi $1-10 \mathrm{~cm}$ yang stabil selama 10 menit dan tidak hilang pada penambahan setetes $\mathrm{HCl} 2 \mathrm{~N}$, menunjukan adanya senyawa golongan saponin.

\section{Analisis Penentuan Total Fenolik \\ Penentuan panjang gelombang maksimum asam galat}

Larutan induk asam galat $100 \mathrm{ppm}$ dibuat dengan melarutkan 0,01 gram asam galat dalam labu ukur $100 \mathrm{ml}$, tambahkan $1 \mathrm{ml}$ etanol kemudian tambahkan akuades sampai tanda batas. Larutan induk $100 \mathrm{ppm}$ kemudian diambil $1 \mathrm{ml}$ dan dimasukkan ke dalam labu takar $10 \mathrm{ml}$, ditambahkan $1 \mathrm{ml}$ pereaksi Folin-Ciocalteu, lalu dikocok hingga homogen. Diamkan selama beberapa menit kemudian tambahkan $4 \mathrm{ml}$ $\mathrm{Na}_{2} \mathrm{CO}_{3} 10 \%$, diamkan selama 15 menit pada suhu kamar. Selanjutnya dilakukan pengukuran dengan spektrofotometer sinar tampak pada panjang gelombang 700 hingga $800 \mathrm{~nm}$ untuk penentuan panjang gelombang maksimum

\section{Pembuatan Kurva Kalibrasi Asam Galat dengan Reagen Folin-Ciocalteu.}

Larutan induk asam galat $100 \mathrm{ppm}$ diambil masing-masing $1 \mathrm{ml} ; 3 \mathrm{ml} ; 5 \mathrm{ml} ; 7 \mathrm{ml}$. Kemudian diencerkan dengan akuades sampai volume akhir $10 \mathrm{ml}$ sehingga diperoleh larutan dengan konsentrasi $10 \mathrm{ppm}$; $30 \mathrm{ppm}$; $50 \mathrm{ppm} ; 70 \mathrm{ppm}$. Dari masing-masing konsetrasi dipipet $0,2 \mathrm{ml}$ lalu dimasukkan ke dalam labu ukur $10 \mathrm{ml}$, ditambahkan $1 \mathrm{ml}$ reagen Folin-Ciocalteu dan dikocok sampai homogen, didiamkan selama 8 menit. Ditambahkan $3 \mathrm{ml} \mathrm{Na}_{2} \mathrm{CO}_{3} 10 \%$ lalu dikocok homogen, dan selanjutnya diamkan selama 30 menit pada suhu kamar. Ukur serapan panjang gelombang serapan maksimum nm, lalu dibuat kurva kalibrasi dengan persamaan regresi y $=\mathrm{bx}+\mathrm{a}$.

\section{Penentuan Kandungan Fenolik Total dengan Metode Folin-Ciocalteu}

Dipipet 0,2 ml ekstrak, ditambahkan 15,8 $\mathrm{ml}$ akuades dan $1 \mathrm{ml}$ reagen Folin-Ciocalteulalu dikocok. Diamkan selama 8 menit kemudian tambah $3 \mathrm{ml} \quad \mathrm{Na}_{2} \mathrm{CO}_{3} 10 \%$ ke dalam campuran. Diamkan larutan selama 1 jam pada suhu kamar. Diukur serapannya dengan spektrofotometer UVVis pada panjang gelombang maksimum. Dilakukan tiga kali pengulangan sehingga kadar fenol yang diperoleh hasilnya didapat sebagai $\mathrm{mg}$ ekuivalen asam galat/g sampel segar.

\section{Penentuan Aktivitas Antioksidan}

Aktivitas antioksidan dianalisa terlebih dahulu dengan membuat larutan DPPH $(1,1-$ diphenyl-2-phikril-hidrazil) dengan melarutkan kristal DPPH kedalam methanol pada konsentrasi $0,01 \mathrm{M}$ dan ditambahkan metanol hingga volumenya $5 \mathrm{ml}$,lalu diukur absorbansinya pada panjang gelombang $515 \mathrm{~nm}$ sebagai absorbansi control, selanjutnya ekstrak sampel diukur dengan mengambil $200 \mathrm{mg}$ ekstrak dan dilarutkan dalam $5 \mathrm{ml}$ metanol sambil memvortek selama 1 jam. Kemudian, diambil $1 \mathrm{ml}$ campuran dan ditambahkan $1 \mathrm{ml}$ DPPH 0,01 M serta metanol hingga volumenya $5 \mathrm{ml}$. Kemudian sampel diukur absorbansinya pada panjang gelombang 517 nm.kemudianInhibition Concentration $\left(\mathrm{IC}_{50}\right)$ (\%) dihitung dengan persamaan :

$$
\% \text { Hambatan }=\frac{A_{\text {kontrol }}-A_{\text {sampel }}}{A_{\text {kontrol }}} \times 100 \%
$$

Ket :

$\mathrm{A}_{\text {kontrol }}=$ Absorbansi tidak mengandung sampel $\mathrm{A}_{\text {sampel }}=$ Absorbansi sampel

\section{HASIL DAN PEMBAHASAN}

Analisis Fitokimia

Hasil uji fitokimia disajikan pada Tabel 1.

Tabel 1. Uji Fitokimia

\begin{tabular}{ccccccc}
\hline \multirow{2}{*}{ Sampel } & \multicolumn{5}{c}{ Uji fitokimia } \\
\cline { 2 - 6 } & alkaloid & flavanoid & Saponin & Fenolik & Triterpenoid & Steroid \\
\hline Ekstrak Daun Muda & + & - & + & + & - & +++ \\
Ekstrak Daun Tua & ++ & - & ++ & ++ & - & ++ \\
\hline
\end{tabular}

Ket : (-) : negatif; (+) : positif tapi lemah; (++) : Positif kuat; (+++) : Positif dan sangat kuat

Ekstrak etanol sampel tanaman dianalisis kandungan senyawa kimianya dengan tes uji warna menggunakan beberapa pereaksi. Uji ini dilakukan untuk mengetahui keberadaan 
senyawa-senyawa flavonoid, fenolik, alkaloid, steroid/terpenoid, dan saponin. Senyawa tersebut menentukan ciri senyawa aktif penyebab efek racun atau efek yang bermanfaat, yang ditunjukan oleh ekstrak tumbuhan kasar yang diuji dengan systembiologi [7]. Hasil uji tersebut dapat dilihat pada tabel 1 .

\section{Uji Flavanoid}

Analisis terhadap sampel daun tanaman yang di ekstraksi dengan pelarut etanol diperoleh bahwa sampel tanaman yang di uji semuanya tidak mengandung senyawa flavonoid,tidak adanya kandungan senyawa Flavanoid dalam hasil uji ini disebabkan karena ada beberapa senyawa terpenoid memiliki struktur siklik berupa alkohol yang menyebabkan senyawa ini cenderung bersifat semi polar sehingga ikatannya dengan pelarut etanol yang bersifat polar sangat lemah [7].

\section{Uji Alkaloid}

Analisis terhadap sampel daun tanaman yang diekstraksi dengan pelarut etanol dan diperoleh bahwa sampel tanaman yang di uji semuanya mengandung senyawa alkaloid. Prinsip dari metode analisis ini adalah reaksi pengendapan yang terjadi karena adanya penggantian ligan. Atom nitrogen yang mempunyai pasangan elektron bebas pada senyawa alkaloid dapat mengganti ion Bi pada pereaksi Mayer. Nitrogen sebagai bagian dari sistem sikliknya pada senyawa alkaloid mempunyai substituen yang bervariasi seperti gugus amina, amida, fenol dan metoksi sehingga bersifat semipolar [8]. Pada uji alkaloid dengan pereaksi Mayer akan terjadi reaksi antara nitrogen dengan ion kalium $\left(\mathrm{K}^{+}\right)$ membentuk kompleks kalium alkaloid yang mengendap. Senyawa alkaloid memiliki efek berupa pemicu sistem syaraf, menaikkan tekanan darah, mengurangi rasa sakit, antimikroba, obat penenang, obat penyakit jantung dan antidiabetes.

\section{Uji Fenolik}

Analisis kandungan senyawa fenolik pada ekstrak daun samama menunjukkan terdapat senyawa fenolik pada ekstrak daun muda dan sangat kuat pada daun tua, hal ini menjadi indikasi untuk melanjutkan berapa kandungan fenolik total yang dimiliki oleh ekstrak daun Samama ini. Fenolik memiliki cincin aromatik dengan satu atau lebih gugus hidroksi (-OH) dan gugus-gugus lain penyertanya. Kelompok terbesar dari senyawa fenolik adalah flavanoid akan tetapi pada uji fitokimianya, tidak terdapat senyawa flavanoid pada daun. Senyawa fenolik yang ada kemungkinan senyawa fenol seperti fenol monosiklik, fenil propanoid, polifenol (lignin, melanin, tannin), dan kuinon fenolik.

\section{Uji Steroid/Triterpenoid}

Analisis terhadap sampel daun tanaman yang diekstraksi dengan pelarut etanol dan diperoleh bahwa sampel tanaman yang diuji semuanya tidak mengandung terpenoid tapi mengandung steroid. Analisis ini didasarkan pada kemampuan senyawa steroid dan terpenoid membentuk warna oleh asam sulfat pekat yang sebelumnya dilarutkan dalam kloroform, tidak adanya kandungan senyawa terpenoid dalam hasil uji ini disebabkan karena ada beberapa senyawa terpenoid memiliki struktur siklik berupa alkoholyang menyebabkan senyawa ini cenderung bersifat semipolar sehingga ikatannya dengan pelarut etanol yang bersifat polar sangat lemah. Steroid memiliki kerangka dasar terpenoid yang membentuk suatu cincin siklopentana prehidrofenantrena. Senyawa steroid yang terdapatdalam tumbuhan dapatberperan sebagaipelindung untuk menolak serangan mikroba penyebab penyakit pada tumbuhan dan hewan [7].

\section{Uji Saponin}

Analisis terhadap sampel daun tanaman yang diekstraksi dengan pelarut etanol dan diperoleh bahwa sampel tanaman yang diuji semuanya membentuk busa pada hasil uji menunjukkan adanya glikosida yang mempunyai kemampuan membentuk buih dalam air. Glikosida berfungsi sebagai gugus polar dan gugus steroid dan terpenoid sebagai gugus nonpolar. Senyawa yang memiliki gugus polar dan nonpolar bersifat aktif permukaan sehingga saat dikocok dengan air, saponin dapat membentuk misel. Pada struktur misel gugus polar menghadap keluar karena mengikat air (hidrofil) sedangkan gugus nonpolar menghadap kedalam karena takut dengan air (hidrofob). Pada kondisi inilah saponin akan berbentuk busa [9].

\section{Penentuan Kadar Total Fenol}

Hasil Penentuan Kadar Total Fenol

Tabel 2. Hasil pengukuran Absorban Standar Asam Galat

\begin{tabular}{cc}
\hline $\begin{array}{c}\text { Konsentrasi Larutan } \\
\text { standar Asam Galat (ppm) }\end{array}$ & Absorban \\
\hline 100 & 0,084 \\
125 & 0,120 \\
150 & 0,132
\end{tabular}




$\begin{array}{ll}175 & 0,144 \\ 200 & 0,171\end{array}$

Uji Penentuan senyawa kandungan total fenolik pada daun samama dilakukan dengan metode Folin-Ciocalteu. Prinsip metode ini adalah oksidasi gugus fenolik hidroksil. Pereaksi ini mengoksidasi fenolat (garam alkali), mereduksi asam heteropoli menjadi suatu kompleks molibdenum-tungsten (Mo-W). Fenolat hanya terdapat pada larutan basa, tetapi pereaksi ini dan produknya tidak stabil pada kondisi basa. Selama reaksi belangsung, gugus fenolik-hidroksil bereaksi dengan pereaksi Folin-Ciocalteu, membentuk kompleks fosfotungstat-fosfomolibdat berwarna biru dengan struktur yang belum diketahui dan dapat dideteksi dengan spektrofotometer. Warna biru yang terbentuk akan semakin pekat setara dengan konsentrasi ion fenolat yang terbentuk, artinya semakin besar konsentrasi senyawa fenolik maka semakin banyak ion fenolat yang akan mereduksi asam heteropoli sehingga warna biru yang dihasilkan semakin pekat [10].

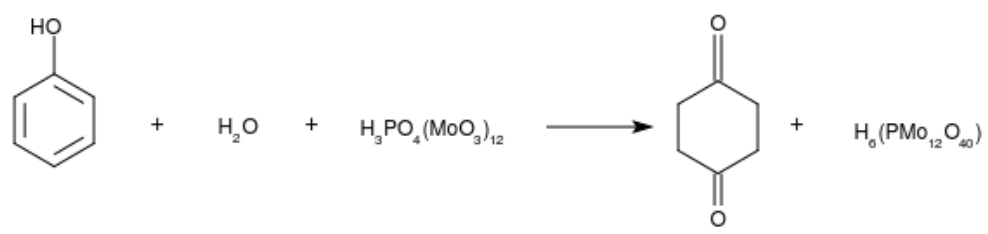

Gambar 1. Reaksi senyawa fenol dengan pereaksi Folin-Ciocalteu

Penentuan kandungan total fenolik ekstrak dilakukan berdasarkan kurva standar asam galat. Penggunaan asam galat sebagai standar, disebabkan karena asam galat adalah turunan dari hidrobenzoat yang merupakan suatu asam fenol sederhana yang bersifat murni dan stabil [11] pembuatan kurva baku asam galat ditentukan dengan mengulang pengukurannya sebanyak 3 kali pengulangan, sampai memperoleh nilai koefisien korelasi yang mendekati $1\left(\mathrm{R}^{2}=1\right.$ atau mendekati 1) berikut kurva standar yang disajikan pada gambar berikut:

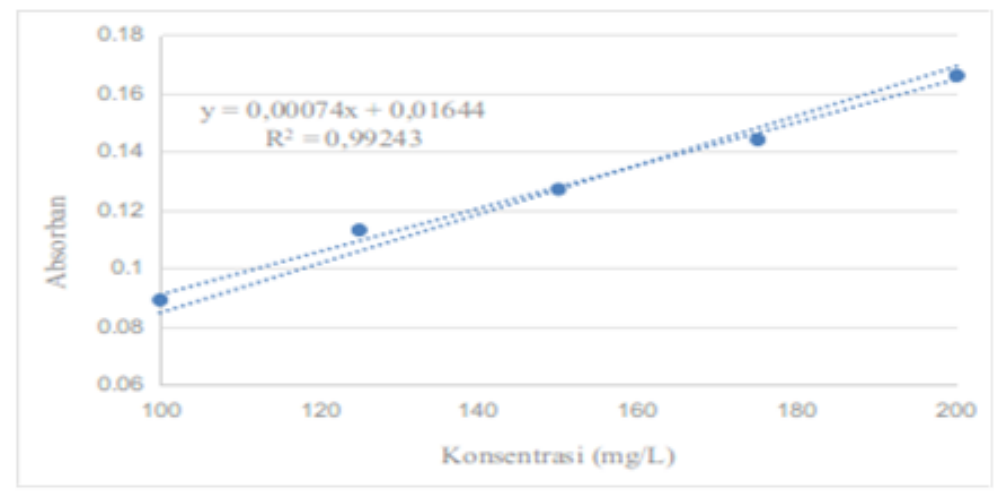

Gambar 2. Kurva standar Asam Galat

Dimana, $y=0,00074 x+0,01644$, dengan koefisien korelasinya $\mathrm{R}^{2}=0,99243$, dengan pengukuran sampel pada panjang gelombang $765 \mathrm{~nm}$ diperoleh nilai absorbansi :

Tabel 3.Nilai Absorbansi Sampel Daun Samama

\begin{tabular}{cc} 
Nama Sampel & Absorbansi \\
\hline Daun Muda & 0,105 \\
Daun Tua & 0,172 \\
\hline
\end{tabular}

Data Hasil Pengukuran kandungan Fenolat total ekstrak Daun Samama

Tabel 4.Kadar Total Fenol

\begin{tabular}{|c|c|c|}
\hline $\begin{array}{l}\mathbf{N} \\
\mathbf{0}\end{array}$ & $\begin{array}{c}\text { Nama } \\
\text { Sampel }\end{array}$ & $\begin{array}{c}\text { KandunganTotal Fenol } \\
(\mathrm{mgGAE} / \mathrm{g})\end{array}$ \\
\hline 1. & Daun Muda & $119,68 \mathrm{mgGAE} / \mathrm{g}$ \\
\hline 2. & Daun Tua & $210.22 \mathrm{mgGAE} / \mathrm{g}$ \\
\hline
\end{tabular}

Pada tabel4, terlihat pada Daun Samama asal Ternate, kandungan total fenol atau fenolik 
total yang dimiliki oleh daun tua lebih besar dibandingkan yang terdapat pada daun yang lebih muda, yaitu 210,22 $\mathrm{mgGAE} / \mathrm{g}$ pada daun tua,yang artinya dalam satu gram ekstrak terdapat 210,22 mg kandungan senyawa fenoliknya. Perbedaan ini didasari bahwa kandungan total fenol pada daun sangat ditentukan oleh umur daun, kondisi tanah, pemberian pupuk serta kondisi lingkungan baik secara biologi, fisik, dan kimia [12].

Hal ini juga sejalan dengan beberapa penelitian sebelumnya yang menyatakan kandungan total fenol berbanding lurus dengan aktivitas antioksidan suatu bahan [13].

\section{Uji Aktivitas Antioksidan}

Pengujian aktivitas antioksidan dilakukan dengan menggunakan standar absorbansi asam askorbat pada panjang gelombang $515 \mathrm{~nm}$. diperoleh kurva standar untuk menentukan koefisien korelasinya, , seperti terlihat pada gambar berikut:

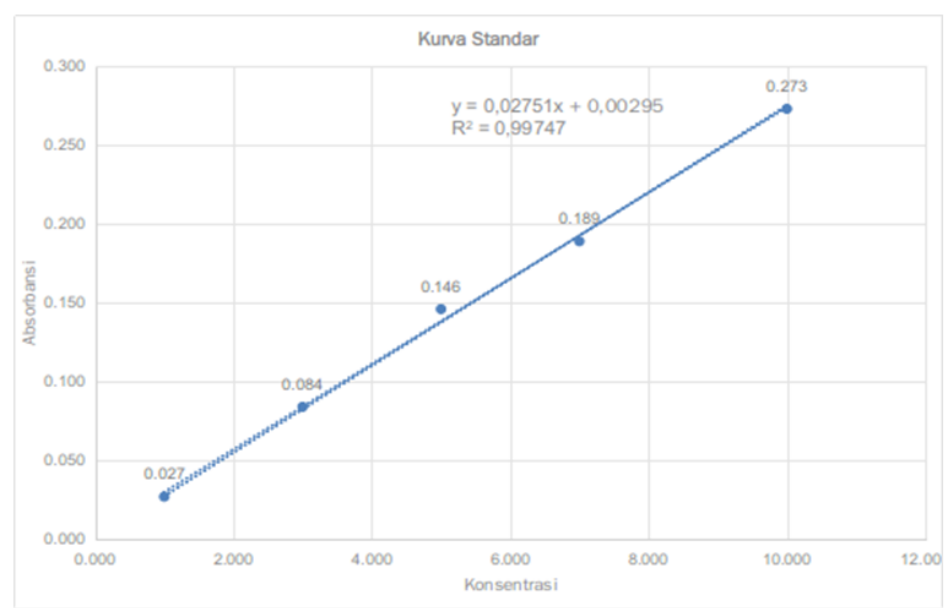

Gambar 3.Kurva Standar Asam Askorbat

Pada uji aktivitas antioksidan terlihat bahwa kedua sampel mengandung aktivitas antioksidan.Penentuan nilai $\mathrm{IC}_{50}$ dilakukan dengan mengalikan nilai konsentrasi yang diperoleh dari tabel berdasarkan kurva standar Asam Askorbat dengan factor pengencerannya (fp) sebesar 10, sehingga diperoleh nilai aktivitas antioksidan sepeerti pada tabelberikut :

Tabel 5. Aktivitas Antioksidan

\begin{tabular}{cccc}
\hline No & Nama Sampel & Nilai $\mathbf{I C}_{\mathbf{5 0}}$ & $\begin{array}{c}\text { Intensitas Kekuatan } \\
\text { Antioksidan }\end{array}$ \\
\hline 1. & Daun Muda & $80.34 \mu \mathrm{g} / \mathrm{mL}$ & Aktif \\
2. & Daun Tua & $43.49 \mu \mathrm{g} / \mathrm{mL}$ & Kuat
\end{tabular}

Daun Tua memiliki nilai $\mathrm{IC}_{50}$ yang lebih rendah, dimana semakin rendah nilai $\mathrm{IC}_{50}$ suatu sampel menunjukkan kemampuan aktivitas antioksidan yang dimilikinyatinggi. Hal ini juga diperkuat dari hasil penentuan kandungan total fenol yang dimiliki oleh daun tua yang lebih besar dibandingkan toal fenol pada daun yang lebih muda, pada pengujian kandungan Fenolik pada ekstrak etanol diperoleh hasil yang sangat kuat.

Pada umumnya senyawa dengan tingkat aktivitas antioksidan yang kuat adalah senyawa golongan fenol yang memilki gugus hidroksi yang tersubtitusi pada cincin bezena dengan poisis orto dan para terhadap gugus $-\mathrm{OH}$ dan $-\mathrm{OR}$.
Golongan senyawa fenol dapat menangkal radikal bebas dengan menyumbangkan protonnya sehingga dapt membentuk radikal yang stabil dengan terjadinya resonansi pada cincin aromatic yang mengakibatkan terjadinya delokalisasi elektron pada elektron bebasnya. Hal ini juga didukung oleh pengujian fitokimia pada daun tua mengandung senyawa fenolik yang lebih kuat dibandingkan pada daun muda [14].

sehingga diperoleh hubungan antara kandungan total fenolik dengan aktivitas antioksidannya $\left(\mathrm{IC}_{50}\right)$, seperti terlihat pada gambar berikut : 


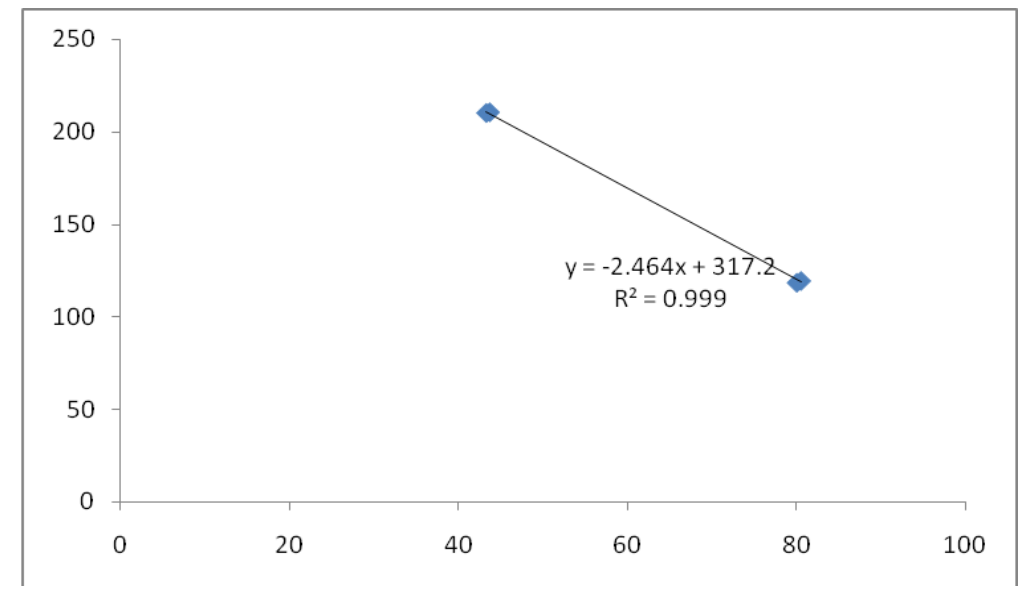

Gambar 4. Kandungan Total Fenolik dengan Aktivitas Antioksidannya $\left(\mathrm{Ic}_{50}\right)$

Dimana persamaan linearnya adalah $\mathrm{y}=$ $2,4647 \mathrm{x}+317,22$ dengan nilai koefisien korelasinya $\mathrm{R}^{2}=0.9996$,. Hal tersebut memperlihatkan bahwa $99,96 \%$ aktivitas antioksidan dipengaruhi oleh kontribusi dari senyawa-senyawa fenolik [15], senyawa fenolik diketahui mampu bertindak sebagai antioksidan dengan memutuskan ikatan rantai radikal bebas secara langsung dan menangkap berbagai spesies reaktif seperti radikal superoksida, hidroksil, peroksil dan asam hipoklorit [16]

\section{KESIMPULAN}

Senyawa metabolik sekunder yang terdeteksi setelah dilakukan uji fitokimia adalah

[1] Rachmaniar. 1994. Penelitian Produk Alam Laut, Skreening Substansi Bioaktif. Laporan Penelitian Proyek Sumber daya laut. Puslitbang Oseanologi LIPI. Jakarta

[2] Nugroho, A.E. 2006. Hewan Percobaan Diabetel Mellitus : Patologi dan Mekanisme Aksi Diabetogenik. Biodiversitas 7 (4) : 378-382

[3] Halawane. J. E., Hidayah. H. N., Kinho. J., 2011. Prospek Pengembangan Jabon Merah Anthocephalus macrophyllus (Roxb.) Havill, Solusi Kebutuhan Kayu Masa Depan. Balai enelitian Kehutanan, Manado, Sulawesi Utara.

[4] Prasidda.dkk. 2016. Potensi senyawa bioktif rambut jagung (zea Mays L.) untuk tabir surya. Jurnal Pangan dan Argoindustri.Vol. 4. No. 1.Universitas Brawijaya: Malang.

[5] Purwaningsih.Dkk. 2015.Efek fotoprotektif krim tabir surya dengan penambahan alkaloid, fenolik, saponin dan steroid, dimana kandungan total fenolik pada ekstrak etanolik daun tua lebih besar dibandingkan pada ekstrak daun muda dengan nilai masing-masing adalah $210,22 \mathrm{mgGAE} / \mathrm{g}$ dan $119.68 \mathrm{mgGAE} / \mathrm{g}$. Nilai $\mathrm{IC}_{50}$ pada ekstrak daun muda sebesar $80,34 \mu \mathrm{g} / \mathrm{mLdalam}$ kategori aktif, dan $43,49 \mu \mathrm{g} / \mathrm{mL}$ untuk Daun Tua berada dlam kategori kuat, serta terdapat hubungan antara kandungan total fenolik terhadap aktivitas antioksidan suatu bahan dengan koefisien korelasi sebesar 99,96\%

\section{DAFTAR PUSTAKA}

kerangginan dan buah bakau hitam (Rhizopora Mucronata Lamk.).jurnal ilmu dan teknologi kelautan tropis. Vol. 7.No. 1.IPB : Bogor.

[6] Harborne. 1987. Metode Fitokimia: Penuntun Cara Modern Menganalisis Tumbuhan, diterjemahkan oleh Kosasih Padmawinata \& Iwang Soediro. Penerbit ITB, Bandung

[7] Harbone, J.B. 2006. Metode Fitokimia: Penuntun Cara Modern Menganalisis Tumbuhan. Edisi Kedua. Bandung : Penerbit ITB. pp 4-147.

[8] Purba, R.D 2001. Analisis Komposisi Alkaloid Daun Handeuleum (Graptophyllum pictum (Linn), Griff) yang Dibudidayakan dengan Taraf Nitrogen yang Berbeda (Skripsi). Bogor: Institut Pertanian Bogor.

[9] Sangi, M., M.R.J. Runtuwene., H.E.I. Simbala,.V.M.A. Makang. 2008. Analisis Fitokimia Tumbuhan Obat di kabupaten Minahasa Utara. Chem. Prog. 1(1):47-53. 
[10] Singleton VL, Rossi JA 1965. Colorimetry of total phenolics with phosphomolybdic phosphotungstic acid reagents. Am J Enol Viticult 16: 144-158.

[11] Lee SE, Hwang HJ, Ha JS, Jeong HS, and Kim JH 2003. Screening of medicinal plant extracts for antioxidant activity.Life Sci. 73: 167-179

[12] Kahkonen MP, Hopia AI, Heinonen. 2001. Berry Phenolics And Their Antioxidant Activity. J Agri Food Chem. 49: 93489351

[13] Huang D., Ou B., Prior RL., 2005, The chemistry behind antioxidant capacity assays. J. of Agricultural and Food Chemistry 53:1841-1856

[14] Rudiansah, 2012, Aktivitas Pengawetan FraksiEtil Asetat Buah Asam kandis ( $G$. DioicaBlum) Terhadap Tingkat Kesegaran IkanNila (Oreochromis niloticus). (Skripsi).

[15] Javanmardi, J., Stushnoff, C., Locke, E. dan Vivanco, J.M. (2003). Antioxidant activity and total phenolic content of Iranian ocimum accessions. Journal of Food Chemistr 83: 547-550.

[16] Nurmi,A, 2008, Antioksidant Studies On Selected Lamiacea Herbs In Vitro And In Humans, Yliopistopaino, University Print, Helsinski, Finland, 33 